\title{
A TENTATIVE CODIFICATION OF THE OLD TESTAMENT LAWS.
}

The Old Testament laws in their present form are a confusing labyrinth in which the modern reader who dares to enter is quickly lost. Civil, criminal, constitutional, humane and ceremonial regulations are mingled together with only an occasional attempt at systematic classification. Primitive and very late laws are also grouped together without distinction, so that it is almost impossible to trace the historical development of a given institution. The inevitable result is that this large and exceedingly important legal literature is practically a terra incognita to most students of law and religion.

The prevailing confusion is primarily due to the fact that these laws come from the East, where systematic arrangement is the exception rather than the rule. The successive re-editing of the Old Testament books in which they are found has also increased the disorder. It is perfectly obvious, therefore, that before the Old Testament laws can be intelligently read and utilized by modern western readers, they must be systematically codified, (I) logically, according to subject matter, and (2) chronologically, within each group, so that the enactments and usages of successive periods can be studied in their true historical order.

The work of logical, scientific classification is here especially difficult, since the Old Testament laws in their origin, character and aims, are fundamentally different from the codes with which we are to-day familiar. In many cases the Israelitish laws do not fit into any of the modern systems of codification, all of which are derived from Roman sources. The peculiar genius' and content of the Old Testament codes must ever be regarded; and where, as in Exodus $21: I$ to $22: 20$ and in certain parts of Deuteronomy a general principle of classification is discernible, it should be followed. At the same time, modern accepted canons of classification must, as far as possible, be adopted if the best practical results are to be achieved.

Fortunately the scientific Biblical scholarship of the past century has definitely distinguished the four or five great original codes that underlie the Old Testament legislation and has determined the approximate date of each. While the decisions which 
Moses rendered and the principles that he promulgated establish forever his position as the father of Israelitish law, the evidence is conclusive that the different codes gradually grew as new needs and new institutions developed in the life of the Hebrew nation. The theory which attributed all Israelitish laws to one man and generation first originated with the later Jewish scribes; but unfortunately it was generally accepted by the Christian Church, and for centuries has tendede to conceal the true character and historical relations of the different Old Testament codes.

The oldest laws, found in Exodus 20:22 to 23:19, bear on their face the evidence of their antiquity. They assume as their basis a primitive nomadic and agricultural life and the simplest family an 1 tribal organization. While they were probably not committed to writing before the ninth or eighth centuries before Christ, they include many customary laws, which doubtless go back to the time of Moses and even earlier. They therefore represent the development of Israel's civil, humane and religious institutions between 1200 and 800 B. C., and may be appropriately designated as the Primitive Codes.

The law book brought forth by the counsellors of King Josiah and by him made the basis of the sweeping reformation instituted in $6 \mathrm{I} 2 \mathrm{~B}$. C. constitutes the basis of the book of Deuteronomy. This legal book includes many laws found in the primitive codes of Exodus 20 to 23; some of these earlier enactments it also modifies or reverses. The original law book of Josiah has also been supplemented by other regulations; but the laws found in Deuteronomy, as a whole, evidently represent the growth of Israel's legal institutions between 800 and $600 \mathrm{~B}$. C. In part contemporary with the Deuteronomic codes are a group of laws found in Leviticus 17 to 26 . Some of them are evidently very old; many of them were known to Ezekiel, who wrote between 592 and 572 B. C.; most of them appear to have been committed to writing early in the Babylonian exile. Since they constantly emphasize the obligation of Jehovah's people to be holy in act and ceremonial, the collection as a whole is known as the Holiness Code.

The destruction of the temple at Jerusalem in $586 \mathrm{~B}$. C. and the transportation of many of the Jewish priests to Babylonia gave them the leisure and a powerful incentive to edit and expand their laws and above all to record in permanent literary form the customary usages and ceremonial institutions that had grown up about the pre-exile sanctuary. The priestly editors also improved the opportunity to correct defects in the older system and still further 
to expand the ritual that it might meet the demands of the changed situation. Ezekiel's code in chapters 40 to 48 of his prophecy illustrates this tendency. It proposes a new program for the restorel Jewish community; and yet it is based on earlier ceremonial customs. Many other priests in the leisure of the exile devoted themselves to collecting and codifying older laws and formulating new ones. The ritual commanded their chief attention. The results of their labors are preserved in parts of Exodus, Leviticus and Numbers; the groups of laws that thus grew up between 600 and $400 \mathrm{~B}$. C. are known as the Priestly Codes.

At the request of the editors of the YALE LAw JournaL NAL the following tentative codification of the Old Testament laws is submitted for criticism and suggestion. The classification, when revised, will be made the basis of the fourth volume of my Student's Old Testament, which will include a new translation of the laws, with introductions and notes.

Charles Foster Kent. 


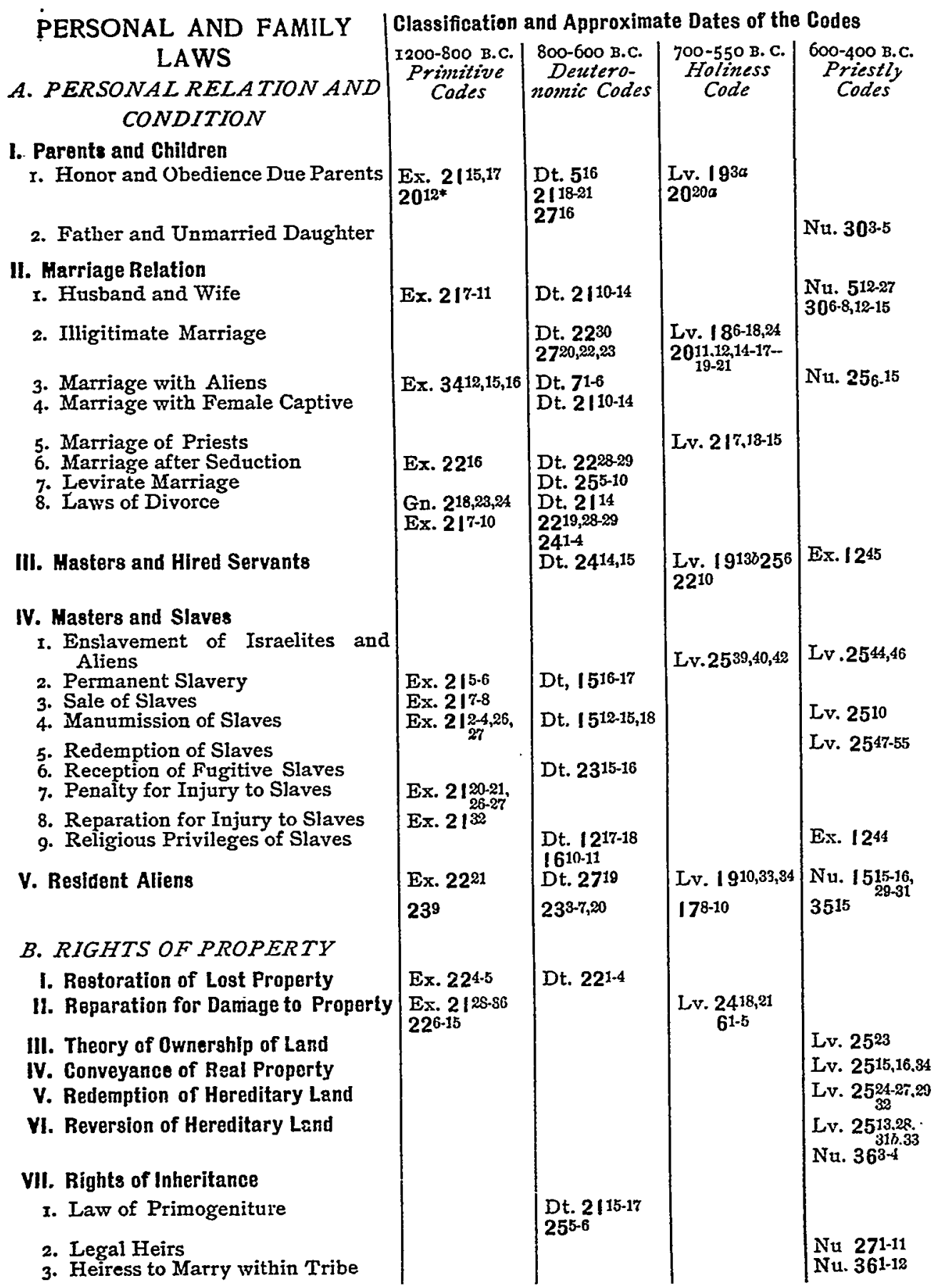




\section{CONSTITUTIONAL LAWS}

A. POLITICAL ORGANIZATION

1. Qualification for Citizonship

I. The Census

III. Division of the Land

IV. Rulers in General

V. The Kingship

B. MILITARY REGULATIONS

I. Organization of the Army

I. Legal Age of Service

2. Exemptions from Service

3. Officers

II. Coremoniai Gleanliness of Army

III. Manner of Attack

IV. The Spoils of War

C. THE JUDICIARY

I. Appointment of Judges

II. Duties of Judges

HI. The Supreme Court of Appeal

IV. Number of Witnesses Required to Convict

V. Daties of Witnes8es

VI. Punishment of False Witnesses

Vil. Exeoution of Judicial Sentenos

ViII. Punlshment for Contempt of Court

IX. Object of Citiss of Refuge

D. PUBLIC INSTRUCTION

I. Publishing the Law

H. Publio Reading of the Law

III. Instruction of Ghildren

\section{CRIMINAL LAWS}

1. Crimes Against Jehovah

r. Worshiping other Gods
Classification and Approximate Dates of the Codes. roo-800 B. C.

Codes

.

Josh. 182-10

1947

Ex. 2228

I. Sam. 3024

Dt. 205-8

245

Dt. 200

[1-15

Dt. 239-14

Dt. 201-4,10-12

Dt. 2010-20

$71,2,16,22-24$

33-6

2!10-14

Ex. 1812-26

2413-14

Ex. 236,8

Dt. 1618

Dt. $1618-20$

|16-17

27252 [1-9

$251-2$

Dt. 178-11

Dt. $1915 ! 76 a$

Dt. $520 / 77 a$

Ex. 231-2

2016

Dt. 1916-21

Dt. 2528

Dt. $1712-13$

Ex. $21^{12-14}$

Dt. 191-13

441-43

Dt. 271-4,8

Josh. $830-32$

Dt. 3/10-18

Josh. 883-85

Dt. 66-7,20-25

I) 18-21

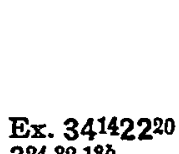

324,82,185

Dt. 57614-16

810-20
I 16-17,26-28

3017-18

1727 
CRIMINAL LAWS

(Continued)

I. Crimes Against Jehovah

2. Apostasy

3. Idolatry

4. Divination and Sorcery

5. Sacrifice of Children to Heathen Gods

6. Blasphemy

7. False Prophecy

8. Desecration of Sacred Things

9. Labor on the Sabbath

H. Crimes Against the State

r. Bribery

2. Perjury

3. Perverting Justice

4. Defiance of the Law

III. Crimes against Morality and Decency

I. Adultery

2. Seduction

3. Ưulawful Marriage

4. 'Sodomy

5. Bestiality

6. Prostitution

7. Immodesty of Women

8. Interchange of Dress

9. Unnatural Mixtures

ro. Kidnapping

II. Covetousness

12. Lying

W. Crimes agalnst the Person

I. Dishonoring Parents

2. Murder

3. Assault

4. Personal Injury

5 Rape

6. Wronging the Defenseless

7. Slander
Classifieation and Approximate Dates of the Codes.

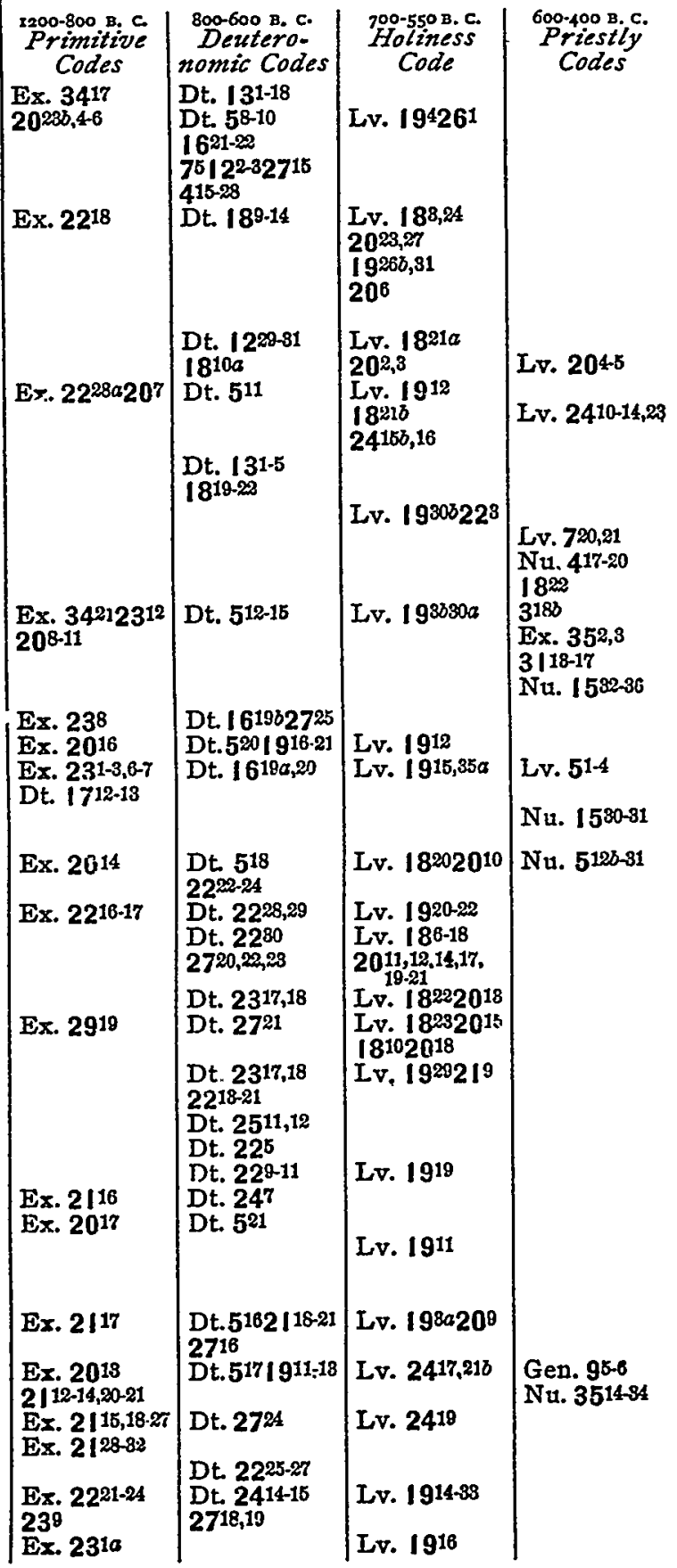


CRIMINAL LAWS (Continued)

\section{v. Crimes against Property}

I. Theft

2. False Weights and Measures

3. Land Stealing

4. Damage by Fire

5. Trespass

\section{HUMANE LAWS}

1. Kindness towards Animals

r. The Threshing $\mathrm{Ox}$.

2. Wild Animals

3. Beasts of Burden

4. The Mother and her Young

11. Consideration for the Unfortunato

I. In Taking Pledges

2. Return of Garments Taken in Pledge

3. Not to Take Mill-stone in Pledge

4. Precaution against Accident

III. Treatment of Dependent Classes

I. Hired Servants

2. Slaves

3. Captives

4. The Defenseless

5. The Poor

IV. Various Philanthropic Provisions for the Needy

x. Leaving the Gleanings

2. Sharing Offerings

3. Distribution of the Tithe

4. Remission of Interest

OBLIGATIONS TO JEHOVAH I. National

I. To Abstain from Apostasy and Idolatry

2. To Abstain from Heathen Rites

3. To Abolish Heathen Shrines

4. To Preserve the Law

5. To Study and Remember the Law

6. To Wear Constant Reminders of the Law
Classification and Approximate Dates of the Coules

\begin{tabular}{c|c|c|c} 
1200-800 u. c. & $800-600$ B. c. & $700-550$ B. c. & Poo-400 B. 0 \\
Primitive & Deutero- & Holiness & Priestily
\end{tabular} Codes nomic Codes Code

\begin{tabular}{l|l|l|l|l} 
Ex. 2015 & Dt.5192324,25 & Lv. 1911713b & Lv. 62-7
\end{tabular}

221-4

Ex. 226

Ex. 225

Dt. 2513-16

Lv. $1935-37$

Dt. 19142717

Ex. 2310,11

Ex. 2212

Dt. 254

\begin{tabular}{l|l} 
Dt. 226,7 & Lv. $25^{5,7}$ \\
Lv. 2227,28
\end{tabular}

Dt. 2410.11

Dt. 2412,13

Dt. 246

Dt. 228

Ex. 2312

Dt. 2414,15

Lv. I 9130

Dt. 1512-15,18 Lv. 2539,40a

Ex. 2222

Dt. 2 /10-14

Dt. 2417,18

2719

Ex. $23^{6}$

Dt. $15^{7-11}$

Iv. $25^{35}$

Dt. 2419,22

Dt. 1610-12

2611

Dt. 1428-29

Ex. $22^{25}$

1 612,13

Dt. 2319,20

Lv. $25^{35-38}$

Lv. 199,10

2322

Ex. 3414-17 201-5,22.23

Dt. 5 ri-10

614-15

2715

Dt. $18^{9}$

$1229 \cdot 31$

141.2

Ex. 3412,13

2324

Dt. 122,3

75-25

Dt. $4^{2}$

Dt. $49 \cdot 146^{6,7}$

II $18 a$

Dt. $\mathbf{6 8 , 9}$

1 I 186-20

$22^{12}$ 
A TENTATIVE CODIFICATION OF OLD TESTAMENT LAWS. $29 I$

\section{OBLIGÁTIONS TO JEHOVAH}

(Continued)

\section{National}

7. To follow its Commands

8. To Make no Heathen Alliances

9. To be a Holy Nation

II Individua!

I. Reverence

2. Gratitude

3. Loyalty

4. Obedience

5. Love

6. Service

\section{CEREMONIAL LAW}

A. SACRED OBJECTS AND SHRINES

I. The Origlnal Tent of Heeting

II. Post Exilic Conception of the Tent of Heoting or Tabernacle

I. The Tabernacle Proper

2. Its Furnishings

3. Its Court

4. Its Service

\section{Pre-Exilic Shrines}

I. The Ark

2. Ancient Altars and Places of Sacrifice
Classification and Approximate Dates of the Codes.

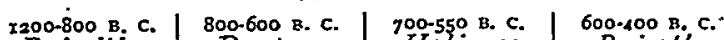

Primitive

Codes nomic Codes

Holiness

Priestly
Pric.

Dt. 51,32,33 Lv. 184,5,26

$68 a, 17 \quad 1919 c, 37$

711-1281,11-14 2018,22

1012,13

$111,8,9,32$

$2616,1745,6$

$2710,263015,16$

Ex. 3412,13,15, Dt. 71-4 $^{1 \cdot 4}$

2331-33

Ex. 2231a/96

Dt. $76142,21 c$ Lv. 1824,25

$18132616-19 \quad 19^{2} 20^{26}$

$\mathbf{2 8 9 , 1 0}$

Dt. $4105^{29}$

$62,18,2486$

$1012,2013^{4}$

$142317^{1}$

$3 \mid 12,13$

Dt. 610,12

810,19

Ex. $34^{142313}$

Dt. 56,7

Dt. 617,18|016

308-10

Dt. 64,5

1012,18

i 1 $1,13-15$

$3015,16,19,20$

Ex. 2325

Dt. 613 [ $0^{12,20}$ Lv. $25^{55}$

Lv. $1932 c$ I I 13,15

Ex. 335-11

Ex. 251-18

261-33

Ex. 2523-40

271.8

Nu. 84

Ex. 3017-21,1-6

Ex. 2634.30

Ex. 279-19

Ex. $25^{30}$

Lv. 245-9

Ex. 2720,21

Lv. $241-4$

Ex. 2938,42

307.10

Ex. 2510-22 


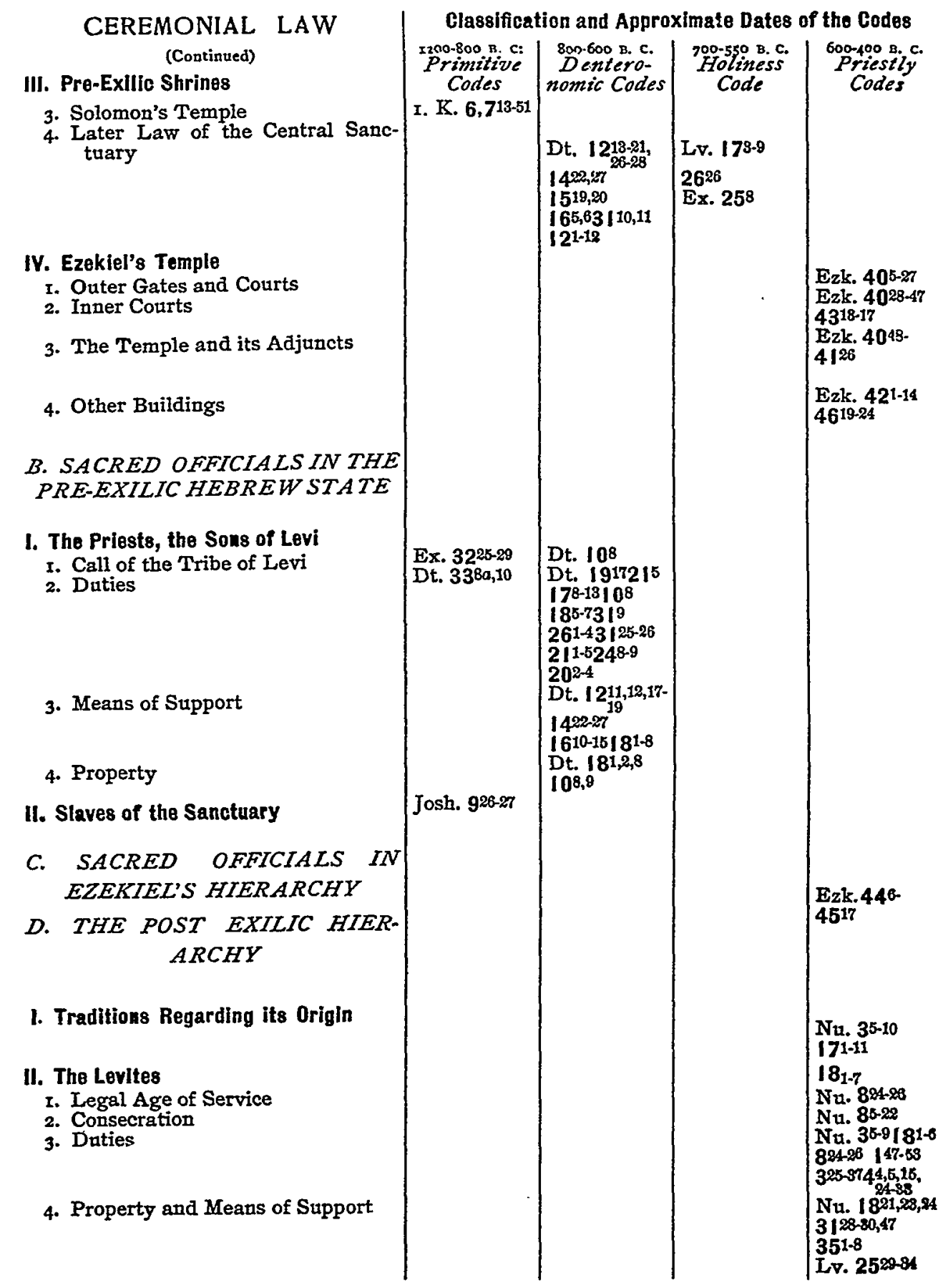


A TENTATIVE CODIFICATION OF OLD TESTAMENT LAWS. 293

\section{CEREMONIAL LAW}

(Continued)

\section{The Prlests}

I. Qualifications

2. Consecration

3. Clothing

4. Caremonial Cleanliness

5. Authority over the Levites

6. Duties

7. Means of Support
Classification and Approximate Dates of the Codes

굴

$800-600$ B. c.
800 rimitive codes

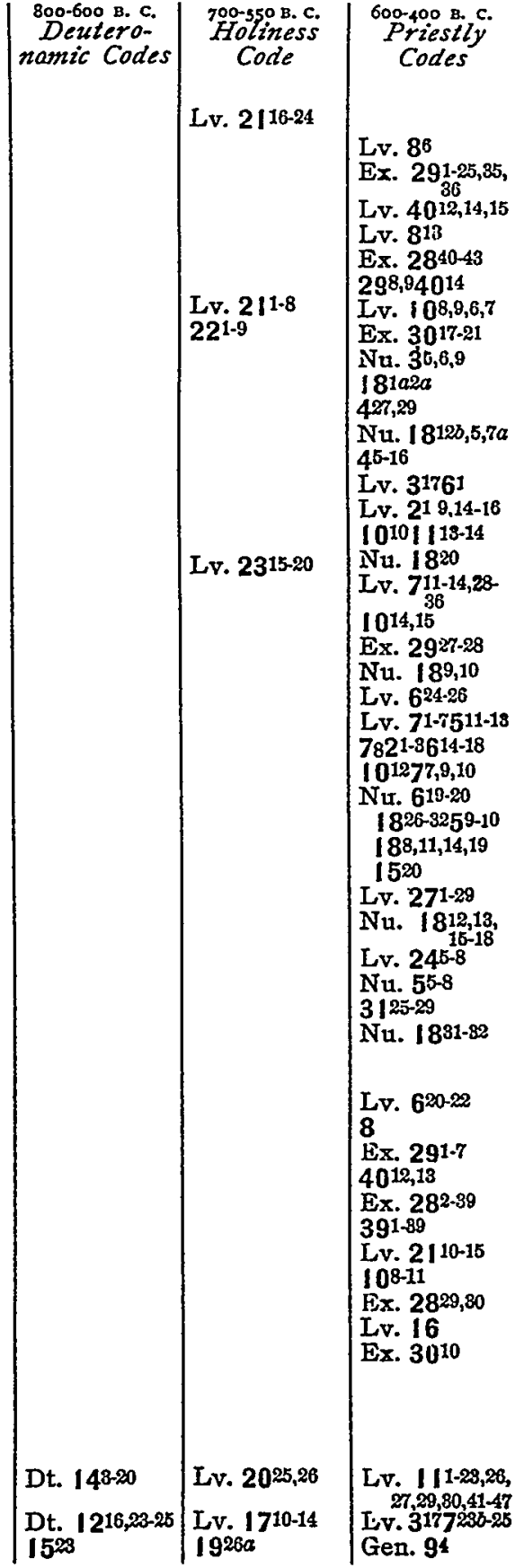

Dt. 1216,23-25

Lv. $1710-1$

Gen. 94

\section{The HIgh Prisst}

I Consecration
2. Clothing
3. Ceremonial Cleanliness
4. Duties

\section{E. REGULATIONS REGARDING CEREMONIAL CLEANLINESS}

1. Foad

r. Clean and Unclean Animals

a. Blood and Fat 


\section{Food}

\section{CEREMONIAL LAW}

3. Flesh of Animals Torn

4. Meat Ceremonially Unclean

5. Leaven Bread

6. Fruit of Young Trees

7. Rules Regarding the Eating of Meat

II. Causes and Purification of Ceremonial Uncleanness

r. Loathsome Diseases

2. Childbirth

3. Contact with the Dead

4. With Carcasses of Unclean Animals

5. With Persons Ceremonially Unclean

6. With Spoils of War

III. Speclal Law of the Nazarites and Priests

F. THE LA WOF CIRCUMCISION

G. THE SACRED DUES

1. First-hern Sons

II. First-born of the Flock and Herd

III. First Fruits

IV. Tithes

V. Poll Tax

VI. Voluntary Offerings

VII. Things Vowed or Devoted

VIII. Spolls of War

H. SACRIFICIAL OFFERINGS

1. Animals Suitable for Sacrifice

II. Different forms of Offering

x. Ordinary Animal Sacrifice

2. The Holocaust

Classification and Approximate Datos of the Coties

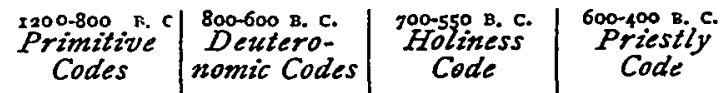

\begin{tabular}{l|l|l|l} 
Ex. 2231 & Dt. $1421 a$ & Lv. 228,9175 Lv. 724
\end{tabular}

Ex. 3425

$2318 a$

Ex. 3410a,20c

22296

$1311,12 c, 18 c-16$ Ex. 3419820a,b 1311-182230 Ex. 3426a 23180

Dt. 1423-27

$15^{19-22}$

Dt. 261-11

184

Dt. 1422-29

2612-15

Ex. 34906

$2229 a$

Dt. 1610-17

125-8

D. $2321-28,18$

1210-12,26

Lv. 1924

2310-11

Lv. 211-15

222-9

Lv. $22^{18,19}$

Lv. $719 a$ Ex. $12^{18-20}$

Lv. 1923-25

LV. $173-8$

2210-16

Lv. $7^{16-18}$

Lv. $224 a$

Lv. 1345,46

Nu. $51-4$

Lv. 1415

Lv. 121.8

Nit. I911 21

3119

Lv. $5^{2}$

I [ 8,24-27.31-40

Nu. 1920

Lv. $5^{3}$

Lv. I55-12,19-

Nu. 3$\}^{270-24}$

Nu. 62b-12

Gen. 172-14

214

Lv. $12^{8}$

Ex. 1248

Ex. 132

311-18,44-51

816-18

Nu. $1815-18$

Lv. 2726,27

Nu. 1518-21

Lv. 214-16

Lv. $2739-39$

Nu. $1826-82$

Ex. 3012-16

Nu. 62-21

Lv. 271-29

Nu. 3125-54

Lv. $12 b, 8$

2219-20

Lv. 31-7

Ex. 1024,25 Dt. $125,6,11,12$

1812

Gen. 820

Ex. 2024

Dt. 278 
CEREMONIAL LAWS

(Continued)

II. Different Forms of Offering
3. Cereal Offerings
4. Drink Offerings
5. Showbread
6. Incense

III. Different Kinds of Offerings

I. Peace Offerings

2. Guilt Offerings

3. Sin Offerings

4. Yearly Sin Offering

5. The Red Heifer

6. Leprosy Offerings

7. Jealousy Offerings

8. Dally Sacrifice

f. THE PRE-EXILIC SACRED $C A L E N D A R$

\section{Passover}

II. Sabbath

III. The Three Annual Festivals

I. Feast of Unleaven bread

2. Feast of Weeks or Harvest

3. Feast of Ingathering or Tabernacles

IV. Sabbatical Year

J. SACRED CALENDAR OF THE POST EXILIC HIERARCHY

I. Now Moon
Classification and Approximate Dates of Codes

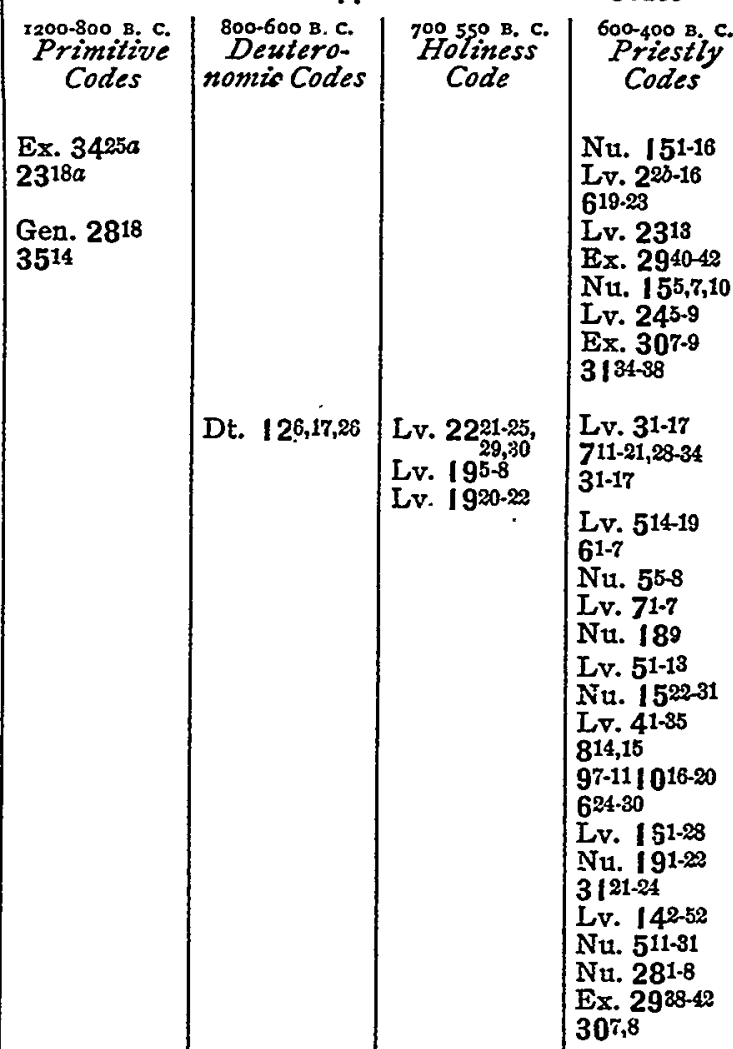

Dt. $161,2,46-7$

Ex. 3425

$2318 b$

1 221-23,25-27a

Ex. 34212312

208-11 / 620-30

Ex. 3423

2314-17

Ex. $341823^{15}$

$133-10$

Ex. $3422 a$

$2316 a$

Ex. 3422

$2316 b$

Ex. 2310,11

DE. 512-15

Dt. 1616,17

Dt. $163,4,8$

Dt. $169-11$

Dt. 1613-15

Dt. $151 \cdot 6$

$2 \mid 10-13$ 
CEREMONIAL LAWS

(Continued)

II. Sabbath

III. Feast of the Passover and Unleaven Bread

IV. Feast of Weeks or First Fruits

V. Feast of Trumpets (New Year's Day)

VI. Day of Atonement

VII. Feast of Tabernacles

VIII. The Sabhatical Year

IX. The Year of Jubilee
Classification and Apprnximate Dates of the Codes 2300-800 B. c. $\mid$ 800-600 B. C. I 600-550 B. c. 1 600-400 B. C.

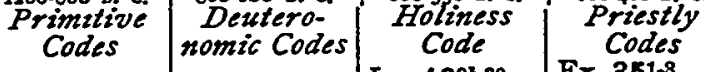
Lv. 1985,30 $26^{2}$

Ex. $351-8$

$3 \mid 12,17$

Gen. 22,8

Lv. 233

Ex. $1611-31$

Nu. $1532-36$

289,10

Lv. $23^{5}$

Ex. $121-14,48$ -

Nu. 91-14

Lv. 23a-8

Nu. 2816-25

Ex. 1216-20

Lv. $23105-21$

Nu. 2826-31

Lv. 2329-25

Nu. 291-6

Lv. 161-34

2326-82

Nu. 297-11

Ex. 3010

Lv. $23_{33-48}^{39-44}$

Nu. 291238

Lv. 251-7,20.22

26 $27-86,43$

Lv. 258-19,23-

Charles Foster Kent. 